of information technologies into them. The latter, firstly, initiate radical changes in private, personal intentions, and secondly, give the activities of public management institutions a new nonlinear and probabilistic character.

Keywords: evolution of privacy, interrelation and interpenetration of private and public, deprivation

КОРНУТА Игорь Васильевич - магистрант кафедры политологии Института истории и политики Московского педагогического государственного университета (119991, Россия, г. Москва, ул. М. Пироговская, 1, стр. 1; i.v.kornuta@outlook.com)

\title{
ТИТУЛ КАК АТРИБУТ КУЛЬТУРНО- ИДЕОЛОГИЧЕСКОЙ ПОДСИСТЕМЫ ОБЩЕСТВА И ПРОБЛЕМА ЕГО ОБНОВЛЕНИЯ
}

\begin{abstract}
Аннотация. Автор статьи, анализируя титул как атрибут культурно-идеологической подсистемы общества, отражающий характер ценностей конкретной политической системы, приходит к выводу, что в условиях Постмодерна, когда в России и странах Запада утвердились нормы правового государства и гражданского общества, необходимо обновить сообразно этим нормам архаику титулов, противоречащих демократическим принципам XXI в.
\end{abstract}

Ключевые слова: титул, власть, политическая система, государство, государственность, политическая культура

егодня в политологии принято разделять такие понятия, как государство, представляющее собой основу институциональной подсистемы общества, и государственность, являющуюся структурным «элементом культурно-идеологической подсистемы» [Асонов 2018: 8]. Если признаками государства в первую очередь выступают политическая власть, право, население и территория, то государственность является свойством исторического развития страны, запечатленным в национальной системе ценностей, отраженным в официальной идеологии и символах, указывающих на специфику социально-политического устройства. Здесь роль символов играет не только набор знаковых атрибутов в виде герба, флага и гимна, но и комплекс титулов, демонстрирующих характер политической культуры данного государства. Но, как известно, «жизненные циклы у каждой политической культуры свои, и свой ресурс времени» [Асонов 2019б: 45]. Поэтому ее новое качественное изменение должно создавать новые знаки и титулы, отвечающие духу эпохи. Однако это не происходит.

Если мы обратимся к государственной геральдике европейских стран, то легко заметим ее несоответствие заявленным демократическим ценностям. Сходная ситуация наблюдается и в области титулатуры. В данном логическом ключе серьезное значение обретает вопрос об их качественном обновлении в циркуляции меняющейся терминологии, которая используется для управления, составления нормативных актов и экспертных оценок. Сегодня существует широкий комплекс политологических инструментов, позволяющих изменить устаревшие символы, пришедшие из прошлого по схеме «премодерн - модерн - постмодерн». В рамках этой триады, предложенной А.Г. Дугиным, был раскрыт весь спектр цивилизационных трансформаций в зависимости от ключевых изменений их идейной базы [Корнута, Кутузов 2017]. Изменения 
идейной базы подчеркивают необходимость оценки адекватности предлагаемых терминологических систем, особенно если анализ проблемы строится в контексте Realpolitik (действительной политики), протекающей в условиях XXI в., когда возрастает необходимость практического использования политической науки, идеологии и образования как комплексного условия нашего выживания. Данная проблема обозначена в виде преадаптивной технологии, раскрывающей роль перманентного анализа и создания предварительно адаптированных технологий управления, т.е. изменений шаблонов политической игры до уровня понимания противоположной стороной поменявшихся правил.

Таким образом, переосмысление прежних стандартных титулов как атрибута культурно-идеологической подсистемы общества может иметь большое значение для демократизации государственной власти. Для этого необходимо обратиться к исследованию цивилизационно-временных парадигм. В частности, одним из ключевых элементов перехода из Премодерна (феодализм) в Модерн (Новое время) является мировоззренческий фактор, меняющий наше осмысление мира. И если в условиях феодализма земля понималась как самый низкий естественно-природный деноминатор feudum, то на первом базовом уровне во времена Премодерна барония была основой земельного титула и сюзеренитета в стратификации регионов. Барония в рамках феодальной политической системы Запада - это в первую очередь замок. Причем понятие «замок» несло в себе еще одно смысловое значение - statecraft (искусство управления страной). Ведь в Средние века замок являлся основой могущества правителя. Поэтому в монархической системе Премодерна он, включая в себя двор местного правителя (дворец), рассматривался в качестве столицы баронии, чего нельзя, например, сказать о республиках той поры вроде Венеции, где появление столицы не связано с наличием замка.

Уровнем выше находилось графство, включающее в себя ряд бароний. Титул графства мог быть спорным, номинальным (если нет земли). Иными словами, номинальность титула подчеркивала престижный (созданный ради чести) характер политической претензии на феод, столицей которого становился замок самой крупной баронии. Но если граф назначался на свою должность сюзереном (королем), то герцог, стоявший во главе бароний, отличался от графа тем, что был связан кровными узами с королевским домом. Это либо родственник правителя страны, либо побежденный король, лишившийся суверенитета и признавший себя вассалом победителя. Вспомним герцогов Бургундских, попавших в зависимость от франков и мечтавших вернуть своему феоду суверенитет, а себе - королевский титул. Именно эта политическая цель толкнула их в эпоху Столетней войны на союз с Англией. Соединение в руках независимого правителя нескольких графств или даже бароний, как это имело место в Наварре, давало ему право на титул короля. Династический союз или иная форма политического объединения ряда королевств, скажем, Германского, Итальянского, Чешского и Бургундского, создавал империю и имперский земельный титул. В нем есть главное королевство, главный герцогский, графский и баронский титул.

В Новое время (эпоха Модерна) развитие экономических отношений меняет приоритет социальных групп и отношение к земле как «универсальному товару». Вместе с этим меняется и характер титулатуры, что нашло отражение в титуле Наполеона I, объявившего себя «императором Французской Республики». К 1804 г. Франция перестала быть королевством, и ее монархический титул перешел в другой титул антикоролевства республику, подчинившую себе ряд королевств. При этом в самой Франции 
главную роль начинают играть буржуа, вставшие на путь рыночных отношений. Революционные события XIX-XX вв. вообще привели к полному поглощению республиканской системой города всех атрибутов земельного баронства, и прежде всего замка, дав начало периоду Постмодерна (Новейшее время), окончательно утвердившему республиканскую систему организации власти.

При этом в культурно-идеологической и нормативно-правовой подсистемах общества почему-то замерли все разработки адекватных аналогов средневековых титулов. На месте королевств и империй возникли новые республики, но на сегодняшний день множество терминов используются синонимично, что даже подчеркнуто в конституциях разных стран. Так, под областью, регионом, провинцией, автономией и даже графством часто понимают одно и то же. В США по инерции небольшие территориальные единицы по-прежнему называются графствами (county). Терминологически «республика» происходит из латинской фразы res publica, что переводят как «общее дело», а «империя» восходит к imperator - «командир» (imperare - командовать), что в условиях современной демократии сильно понижает практическую значимость этого термина, придавая ему негативный характер. Между тем, титулы, связанные с политическим управлением, стали получать те, кто к ним по роду своих занятий и социального происхождения не имеет никакого отношения. С конца XX в. данная мода пришла и в Россию (барон А. Розенбаум, графиня Л. ФедосееваШукшина), а вместе с ней - и наследование привилегированного положения. В таком случае логика титульной иерархии требует наличия императора, ведь у нас восстановлен имперский герб. «Этот геральдический символ был присущ как Священной Римской империи и Византии, так и России», демонстрируя идею «любовного единства православия и самодержавия с обществом» [Асонов, Талина 2016: 107], что противоречит принципу организации светского правового государства, отрицающего сословные перегородки и связанные с ними понятия.

Вот почему для современного политического администрирования представляется важным отказ от ряда исторических символов и переход к новой системе обозначений, как это было в России после свержения монархии в 1917 г. Уход от использования рудиментарных терминов, характерных для другой политической системы, и их смысловое упрощение поможет нам в условиях современного транзитивного общества устранить этимологическую путаницу. Ведь она касается политического дискурса. А он, в свою очередь, выходит на коммуникативную сферу и встраивается «через подвижные отношения между элементами $x$ (наука), $y$ (идеология), $z$ (образование)» [Асонов 2019а: 161] в культурноидеологическую подсистему и ее политическую культуру, обязанную отражать демократические реалии властных отношений в условиях гражданского, а не феодального теократического общества XXI в.

\section{Список литературы}

Асонов Н.В. 2018. Цивилизационные основы российской государственности. - Социально-гуманитарные знания. № 9. С. 7-15.

Асонов Н.В. 2019а. Политология в транзитивном обществе: смыслы и заблуждения. - Власть. Т. 27. № 5. С. 159-163.

Асонов Н.В. 2019б. Современная политическая культура России как элемент гражданского и религиозного типов общества. - Социально-гуманитарные знания. № 2. С. 39-47.

Асонов Н.В., Талина Г.В. 2016. Генезис российских представлений о власти. - Власть. № 8. С. 103-111. 
Корнута И.В., Кутузов Д.В. 2017. Динамика эволюции субъектности в политике. - Евразийский союз ученых. № 5-1(38). С. 14-16.

\title{
TITLE AS AN ATTRIBUTE OF CULTURAL- IDEOLOGICAL SUBSYSTEM OF SOCIETY AND THE QUESTION OF ITS SCIENTIFIC RENEWAL
}

\begin{abstract}
The article analyzes the concept of title as an attribute of the cultural and ideological subsystem of society, reflecting upon the nature of the values that exist in different political systems. The author concludes, that in contemporary postmodern conditions in Russia and the West, where the constitutional and civil values have withstood the test of time, there is a need to renew archaic and revolutionary title nomenclature that contradicts the democratic principles of the $21^{\text {st }}$ century.

Keywords: title, power, political system, state, statehood, political culture, Postmodern
\end{abstract}

УДК 294. 3(54)

ЖАМСУЕВА Дарима Санжиевна - кандидат исторических наук, доцент; старший научный сотрудник отдела философии, религиоведения Института монголоведения, буддологии и тибетологии СО РАН (670047, Россия, Республика Бурятия, г. Улан-Удэ, ул. Сахьяновой, 6; darisan@ rambler.ru)

\section{РИТУАЛЬНЫЙ АСПЕКТ ХУРАЛА И КРУГОВРАЩЕНИЯ МАЙТРЕЙИ В БУРЯТСКИХ ДАЦАНАХ}

\begin{abstract}
Аннотация. В статье рассматривается ритуальный характер исполнения обряда почитания Майдари - грядущего Будды, анализируются некоторые особенности его проведения в ранний период по историческим источникам и в наши дни. Автор выявляет тенденции роста религиозности среди населения в современном контексте, определяет его причины.
\end{abstract}

Ключевые слова: Майдари, хурал, дацан, религиозный обряд, традиции

Б ольшая часть этнической Бурятии издавна исповедует буддизм. В полной мере мы можем сказать, что под влиянием исторических процессов, сформировавших новый, социалистический образ жизни советского народа, а затем демократических преобразований в стране в сознании верующих бурят произошли определенные изменения. Эту особенность четко демонстрируют результаты этнографических и конкретно-социологических исследований.

Так, исследования, проведенные в 1962-1966, 1972-1976 гг. под руководством доктора исторических наук К.М. Герасимовой, подтвердили общие закономерности глубокого кризиса буддизма в этнической Бурятии в советские годы, необратимые явления распада традиционного комплекса религиозного 